\title{
Stock Picking and Market Timing of the Egyptian Fund Managers: Evidence from the Financial Crisis
}

by

Mohamed Elmessearya ${ }^{\text {** }}$

\begin{abstract}
The findings of over-or-under performance of fund managers across the crisis periods are mixed. By analyzing the data of 35 Egyptian funds, this paper investigates the two skills of market timing and selectivity during-and-post the 2007-2008 financial turmoil; it also examines the comparative performance between the conventionaland Islamic mutual funds. The results show no evidence of these skills even for the overall period or for the crisis one, where Chow - test documents that there are no structural changes either for the regression line or for its coefficients across the two sub-periods. These findings are supported by using a well-known benchmark. Thus, it seems that investors cannot gain superior returns by investing in the mutual funds industry as a whole. Furthermore, the outcomes of the cross-sectional analysis report that investors cannot also attain higher returns by investing in a particular fund group against the other, implying that the ethical screening, which is adopted by the Islamic ones, and which limits their potentials of diversification does not impact their performance.
\end{abstract}

JEL classification: G1; G2

Keywords: Capital markets, Islamic mutual funds, performance evaluation, market timing ability, stock picking ability

\section{Introduction}

The evidence of whether or not fund managers are skilled in stock picking and/or market timing during and after the FC is mixed. By the timeFung et al., (2002); French \& Ko (2007) and Park (2010)originate that there is no statistically significant evidence of market timing ability for fund managers before and during the FC;Fung et al., (2002)suggest that fund managers do demonstrate superior security-selection skills only, While Chen (2007); Chen and Liang (2007); Monarcha (2011) and Cave et al., (2012)exhibit that a number of fund managers can do significantly time their markets pre-and-post the FC. Meanwhile,Kaushik and Pennathur (2012) results reveal that fund managers can significantly out-perform the market, but after accounting for the downmarket of 2007-2008 there is no over-performance, referring that fund managers cannot make stock selection or market timing during the FC.To this end of overlapping and tangling this study offers new empirical evidence from Egypt as an example from Islamic emerging economy with conventional capital market by answering the following research 
questions: Do the Egyptian fund managers make security selection and/or market timing during and after the crisis period? Are there any significant differences between the performance of (CMFs) and their Islamic counterparts? Despite the fact that manager skills has received a great attention of scholars who are interested in the mutual funds' performance, little has devoted his investigations towards emerging economics, especially these of the Middle East, where the markets are less saturated and more accepting of new brands, (Marketing Week, 2012). Hence, it is important to extend the recent literature with evidence from the Egyptian emerging economy and open up new horizons for the international companies especially these, which present the financial intermediation services. Towards this point, this study investigates a sample of 35 diversified mutual funds, divided into two groups: conventional and Islamic by employing two market indexes across two sub-periods: 'the financial crisis period' and covers the two years of 2007-2008 and 'the Post-Crisis period' which holds between 2009 and the mid of 2012 in order to explore the funds' performance over the whole period, and to test the impact of the financial turmoil on the funds access returns, and results of the overall period, in addition to revealing the performance differences between conventional and Islamic mutual funds during the same period. The reminder of this paper is organized as follow. Section 2 presents a brief literature review. Section 3 displays the methodology, data sources, while the empirical tests' results are presented in Section 4 and the conclusions follow in Section 5.

\section{Related literature and empirical hypotheses}

\subsection{Conventional Mutual Funds (CMFs)' performance across the crisis period in developed and emerging economies}

Since the mid-sixties and yet, several studies with several approaches have been used in the literature for measuring how fund managers are skilled in timing their markets and selecting their assets,but the findings are mixed and inconclusive as to whether those managers perform better or worse during-and-post periods of financial turmoil. By the timeKaushik and Pennathur (2012)in US,Keith et al., (2008)in the British economy, Yang-pin etal., (2012)internationally, George et al., (1998)in Canada, YueCheong and Louis (2003)U.S-based Asian, Phaniswara and Mallikarjuna (2009)in India,Craig and Micael (1997)in South Africa,Roberto et al., (2001) in Italy, Amporn and Yosawee (2011)in Thailand,Sit and Manuel (2011)in Philippine,Murhadi (2010)in Indonesia, Reza et al., (2011)in Iran, Shazia et al., (2010)in Pakistan,and Samira and Slaheddine (2011)in Tunis.Find no evidence on the managers' skills of market timing and selectivity; they document that the majority of funds with positive abnormal performance can be attributed to good luck, not only this, but it is extremely difficult expost to isolate these funds, even when they have a long data history. Furthermore, once when accounting for the drop-market conditions of (2007-2008)the coefficient of the downturn dummy variable is negative and highly significant. Hubner et al., (2012)in the U.S, Heaney et al., (2007)in Australia,Evangelos (2009)in Turkey, and Beehary et al., (2009)in Mauritian refer to the existence of the market timing capability between the managers, even if it was slightly weak especially during the turbulent periods like this of (2007-2008), and that there have been considerable periods of time when the individual international funds rolling alphas suggests that the funds out-perform the intended index after adjustment for risk. Shortly, given that the majority of the practical investigations that took place so far have resulted in negative outcomes, it is expected that any trial for 
judging the Egyptian fund managers capabilities across the crisis period will also involve the same negative results. To summarize, the formal specification of the first hypothesis is the following:

Hypothesis 1 (H1): the Egyptian fund managers have not significant selectivity and/or market timing skills within-and-after periods of financial turmoil.

\subsection{Islamic Mutual Funds (IMFs)Performance over the crisis period in different economics}

Islamic mutual funds are running based on Islam principles, under which business and trade activities that generate fair and legitimate profit arepermissible,interest-based transactions are prohibited(Bakri. et al., 2012), while the schemes of risk and profit-sharing and partnership is the base (Christian and Sebastian, 2012). Hereafter, they distinguish themselves from conventional funds by the type of the ethical screening they apply,where, they screen out stocks of companies engaged in making money from alcohol, tobacco, gambling, pornography, pork processing, entertainment and all other such activities that violates Muslim ethical values in terms of usury. They also avoid stocks of companies that use the leverage in their equity structure (Dawood, 2013), inaddition to investments in preferred stocks and bonds, since both promise a fixed rate of return and grant no voting rights (Naughton and Naughton, 2000). But, it seems that these unique features of IMFs are a double edged weapon, where some academics suppose that this crisis would not have occurred under an Islamic financial system, because most, if not all, of its causes are not allowed under guidance and rules of Shari'a (Hassan and Kayed, 2010), meanwhile,some other researchers suggest that their ethical screenings, which limit its potential of diversification will also limit its potential for financial growth (Abul Hassan. et al., 2005).

Unfortunately, the proof of Islamic finance resilience against the FC compared to the conventional one, and the negative impact of their ethical screening on their financial performance is assorted too. The results of applied researches that verified this instance are completely incompatible, whereas, in regard to the first assumption of Islamic finance reliability against the FC, Miranti \& Ilham (2012)in Indonesia and Malaysia,Nafis Alam (2010)in the European market,NafisAlam (2013)in UK, Dawood (2013)inSaudi Arabian, show that the risk-return relationship of IMFs is relatively stable as compared with asset allocation strategy, which means that the portfolio of Shari'ah Compliant equities outperforms this of the CMFs. Secondly, in respect to the impact of ethical screenings and values of IMFs and SRIFs on their financial performance, the findings were also tangled. Where, in US,Luis et al., (2011) show that the "Negative Screens" and "Religious" portfolios show a significant and negative stock-picking ability, while Abul Hassan, et al., 2005 in US, too, and Stefano \& Stefano (2009)in Italy document that the assumption thatexpected returns of Islamic screened portfolios being lower than this of conventional portfolios is completely rejected.Briefly, because the performance differences between IMFs and CMFs were not always significant for the results of the studies that conducted in other Islamic economics, it is also expected to be the same when verifying it in the Egyptian stock market.Thus, the formal specification of the second hypothesis is as follows:

Hypothesis 2 (H2): Within the Egyptian economy, the Islamic mutual funds' performance does not significantly differ from the conventional mutual funds'performance. 


\section{Methodology}

\subsection{Sample selection}

The empirical analysis of this work conducts by investigating a sample of 35 diversified Egyptian mutual funds for the period between 31/12/2006 and 30/06/2012. However, since some academics refer that the market down-turn period of the global FC was confined between the two years of 2007 and 2008 (David H. and Pedro, 2012), it is proper to divide the overall period into two sub-periods: the former is termed as 'the financial crisis period' and covers the two years of 2007-2008 and the latter as 'the PostCrisis period', it holds for the last 3.5 years from $1 / 1 / 2009$ to $30 / 6 / 2012$. This choice is mainly attributed to two main reasons. The first one is to verify the validity of the FC supposition in the Egyptian stock market. While the second reason is that this subdivision enables us making the required comparison between the results of the two periods when investigating the impact of the FC on funds' performance, which is a key purpose for this study. For verifying the impact of the FC on the Egyptian stock markets we run Chow-Test (Chow, 1960),to explore how the regression line and coefficients are stable across the two sub-periods by using F - Ratio. Meanwhile, to test the impact of the FC on the funds' performance we insert a dummy variable to take one for each moth of the first sub-period and zero otherwise, then re-estimate the regression coefficients as a vigorous check.Concurrently, in order tocompile the investigated sample, and to run the proper comparison, the following criteria have been used. First, the sample was restricted to diversified funds that were publicly traded as of June 2012, and guided by the EgyptianCapital Market Authority (ECMA). This results in 87 diversified funds. Second, the sample has been restricted to funds that their life-time exceeds five years by the end of June 2012 in order to keep the funds that witnessed the FC; this also results in 35 diversified funds. Third, for exploring thefund managers' capabilities of selectivity and market timing, a database has been constructed for the selected sample, while all returns are calculated from monthly net asset value (NAV) of funds resulting in returns that are inclusive of any distributions. Fourth, as the standard procedures in mutual funds research requires covering 36 monthly observations at least(Elton, Gruber and Green, 2007), this study covers more than five years (65 monthly observations) for assuring the accuracy of data. Fifth, for improving the comparability, funds are divided into two subcategories: the first one is the conventional funds, while the second category is the Islamic ones. Finally, given the fact thatIMFs investments are subject to Shari'ah constraints, and that their holdings are more concentrated on equities only (Dawood, 2013); it might be proper to compares the performance of IMFs against its equity CMFs counterpart alone when testing the second hypothesis, and to useIslamic benchmark indexesfor explaining the return variation of IMFs compared to the conventional indexes. But since there are no Islamic indexes for the Egyptian stock market, this study conducts by using EGX30index. It also uses the return of 3-monthsEgyptian treasurybill as the risk free rate. Accordingly, Panel A of Table 1 summarizes the sample selection process, while Panel B: displays the selected sample. 
Table 1 Panel A: sample selection

\begin{tabular}{|c|c|c|c|c|c|}
\hline \multicolumn{3}{|c|}{ (n) } & $\begin{array}{l}\text { N. of funds } \\
\text { dropped }\end{array}$ & \multicolumn{2}{|c|}{$\begin{array}{l}\text { Remaining } \\
\text { funds }\end{array}$} \\
\hline \multicolumn{4}{|c|}{ Population of mutual funds } & \multirow{2}{*}{\multicolumn{2}{|c|}{87}} \\
\hline \multicolumn{4}{|c|}{$\begin{array}{l}\text { Less } \\
\text { Funds which didn't witness the beginning of the } \\
\text { FC }\end{array}$} & & \\
\hline \multicolumn{4}{|c|}{ Final Sample } & \multirow{2}{*}{\multicolumn{2}{|c|}{35}} \\
\hline \multicolumn{4}{|c|}{ Panel B: selected funds } & & \\
\hline $\begin{array}{l}\text { Catego } \\
\text { ry }\end{array}$ & $\begin{array}{l}\mathbf{N} \\
\mathbf{o}\end{array}$ & Fund Manager & Fund Name & $\begin{array}{l}\text { Fund } \\
\text { Type }\end{array}$ & $\begin{array}{l}\text { Incept } \\
\text { ion } \\
\text { date }\end{array}$ \\
\hline \multirow{17}{*}{$\begin{array}{l}\text { Conve } \\
\text { ntionl }\end{array}$} & $\begin{array}{l}1 \\
2 \\
3 \\
4\end{array}$ & Hermes Funds Management & $\begin{array}{l}\text { Credit Agricole Egypt I } \\
\text { Bank of Alexandria I } \\
\text { Banque du Caire } \\
\text { Credit Agricole Egypt II } \\
\text { Egyptian Gulf Bank }\end{array}$ & \multirow{6}{*}{ Equity } & $\begin{array}{l}\text { Oct-94 } \\
\text { Dec-94 } \\
\text { Nov-95 } \\
\text { Apr-97 } \\
\text { May-97 }\end{array}$ \\
\hline & $\begin{array}{l}6 \\
7 \\
8 \\
9 \\
10\end{array}$ & HC Securities & $\begin{array}{l}\text { Export Development Bank I (Al- } \\
\text { Khabeer) } \\
\text { Suez Canal Bank I } \\
\text { Banque Misr III } \\
\text { Misr Iran Development Bank I } \\
\text { National Bank of Egypt III }\end{array}$ & & $\begin{array}{l}\text { Oct-96 } \\
\text { Dec-96 } \\
\text { Dec-97 } \\
\text { Jul-98 } \\
\text { Aug-05 }\end{array}$ \\
\hline & 11 & $\begin{array}{l}\text { Arab African Investment } \\
\text { Management }\end{array}$ & Shield Fund & & Feb-98 \\
\hline & 12 & Prime Investment & Arab Misr Insurance Group & & Aug-95 \\
\hline & 13 & C I Asset Management & Commercial International Bank II & & Apr-06 \\
\hline & 14 & $\begin{array}{ll}\text { Concord } & \text { International } \\
\text { Investments } & \\
\end{array}$ & Banque Misr II & & Sep-95 \\
\hline & 15 & HC Securities & Misr Iran Development Bank II & \multirow{6}{*}{$\begin{array}{l}\text { Fixed } \\
\text { Income }\end{array}$} & Jul-05 \\
\hline & 16 & C I Asset Management & $\begin{array}{l}\text { Commercial International Bank I } \\
\text { (Osoul) }\end{array}$ & & Apr-05 \\
\hline & 17 & EFG-Hermes & Bank of Alexandria II & & \\
\hline & 18 & EFG-Hermes & National Societe Generale Bank & & Oct-06 \\
\hline & 19 & $\begin{array}{l}\text { Egyptian Fund Management } \\
\text { Group }\end{array}$ & Credit Agricole Egypt III & & Jun-99 \\
\hline & 20 & Delta Rasmala & Export Development Bank II & & Nov-06 \\
\hline & 21 & & National Bank of Egypt I & \multirow{5}{*}{$\begin{array}{l}\text { Balance } \\
d\end{array}$} & Sep-94 \\
\hline & 22 & Al Ahly Funds Management & National Bank of Egypt II & & Oct-95 \\
\hline & 23 & & National Bank of Egypt IV & & Jul-06 \\
\hline & 24 & $\begin{array}{ll}\text { Concord } & \text { International } \\
\text { Investments } & \end{array}$ & Banque Misr I & & Feb-95 \\
\hline & 25 & Hermes Funds Management & Al Watany Bank of Egypt & & Aug-06 \\
\hline
\end{tabular}




\begin{tabular}{|c|c|c|c|c|c|}
\hline & 26 & Prime Investment & Arab Land Direct & \multirow{3}{*}{$\begin{array}{l}\text { Closed } \\
\text { End }\end{array}$} & Feb-00 \\
\hline & 27 & $\begin{array}{l}\text { Egyptian Investment \& } \\
\text { Finance Co. }\end{array}$ & Orient Trust & & Jan-97 \\
\hline & $\frac{28}{29}$ & $\begin{array}{l}\text { Al Ahly Development \& } \\
\text { Investment }\end{array}$ & Misr Direct Investment Fund & & Jul-99 \\
\hline & 29 & \multirow[b]{2}{*}{ Prime Investment } & Societe Arab Int'l Banque I & Asset & Jun-96 \\
\hline & 30 & & Societe Arab Int'l Banque II & $\begin{array}{l}\text { Allocat } \\
\text { or }\end{array}$ & Oct-97 \\
\hline & 31 & Prime Investment & Al Rabeh Fund & $\begin{array}{l}\text { Income } \\
\text { Mixed }\end{array}$ & Feb-99 \\
\hline \multirow{4}{*}{$\begin{array}{l}\text { Islami } \\
\text { c }\end{array}$} & 32 & HC Securities & Banque Misr IV & \multirow{4}{*}{$\begin{array}{l}\text { Islami } \\
\text { c }\end{array}$} & Oct-06 \\
\hline & 33 & $\mathrm{Al}$ Ahly Funds Management & Egyptian Saudi Finance Bank & & May-06 \\
\hline & \multirow[t]{2}{*}{34} & C I Asset Management & $\begin{array}{l}\text { Faisal Islamic Bank-CIB (Al } \\
\text { Amman) }\end{array}$ & & Oct-06 \\
\hline & & EFG-Hermes & Faisal Islamic Bank & & Dec-04 \\
\hline
\end{tabular}

Source: Egypt for Information Dissemination (EGID) - Monthly report, June 2012.

\subsection{Performance measures}

\subsubsection{Fund manager's skill (stock picking and market timing)}

Following Jensen's alpha, this paper evaluates the ability of fund manager to select the appropriate investments for his portfolio by the following generalized CAPM based regression model.

$$
R i t-R f t=\alpha i+\beta i(R m t-R f t)+\varepsilon i t
$$

Where $R_{i t}$ is the return on fund $i$ in month $t . R_{f t}$ is the return on the 3-month Egyptian T-bill in month $t . R_{m t}$ is the return on the Egyptian general index in month $t$. $(R m t-R f t)$ is the exess monthly return on market index, while $\varepsilon_{i t}$ is the error term. The intercept $a_{i}$ is the Jensen's alpha, which is consistently represent a measure of stock picking ability of the fund manager and $\beta_{i}$ (beta) is the systematic risk.

Meanwhile, following the basic Treynor and Mazuy (1966) model, which separates the performance of fund managers into three components, this paper measure the Egyptian fund managers ability of timing the market as follow:

$$
R i t-R f t=\alpha i+\beta i(R m t-R f t)+\gamma i(R m t-R f t)^{\wedge} 2+\varepsilon i t
$$

(2)

Superior market timing ability shows up in positive $\gamma_{i}$. While $a_{\mathrm{i}}$ and $\beta_{i}$, are coefficients indicating stock selection and systematic risk of funds. However, to test whether or not Egyptian fund managers do selectivity and/or market timing during the (FC) then to capture the impact of downturn period; Kaushik and Pennathur (2012) suggest creating a down dummy variable (dummonthi) to take a value of 1 if the period is between January 2007 and December 2008 and zero otherwise, which means computing the fund alpha using the two previous models for the entire 2007-2012 period, then using a dummy variable to indicate the market fall of 2007-2008 period and re-estimate the regression coefficients (alpha and gamma), which allow drawing interpretations on how the market downfall impacts the fund managers practices and performances. 


\subsubsection{Stability of the regression line}

Following Chow-Test, (Chow, 1960), the investigation of whether or not the regression line and coefficients are stable across the two sub-periods will be measured by the following F - Ratio.

Where:

$$
F=\frac{(a-b)}{p} \div \frac{b}{(n-2 p)}
$$

$a=R s s_{p}:$ is the residual sum of square for the entire period.

$b=R s s_{p 1}+R s s_{p 2}:$ are the residual sum of square for the two sub-periods $p_{1}$ and $p_{2}$.

$n:$ the number of observations.

$p:$ the number of parameters.

While the null hypothesis can be accepted at 5\% and $1 \%$ levels if the $F$ value was lower than 3.01 and 4.64 respectively, which mean that there are no any structural changes for the regression line across the two sub-periods.

\subsubsection{Performance differences between equity conventional and Islamic mutual funds}

To investigate the differences between the estimated coefficients of the two categories of the Egyptian equity $\mathrm{CMF}_{\mathrm{S}}$ and $\mathrm{IMF}_{\mathrm{S}}$ and then measuring how their performance are significantly differ Hayat and Kraeussl (2011) propose a method under which alpha and beta coefficientsof each funds group, obtained by regressing the excess return of each fund $\left(\mathrm{R}_{i t}-\mathrm{R}_{f t}\right)$ against the excess return of the market portfolio $\left(\mathrm{R}_{m t}-\mathrm{R}_{f t}\right)$, are statistically compared in order to assess the significance of differences between their performances. Accordingly, alpha and beta coefficients are obtained using the (CAPM) regression between the funds excess return and the EGX30 excess return with Neweywest hetroscedasticity and auto correlation (HAC) robust-standard errors. The differences in mean and standard deviation of the estimated alphas and betas are performed by using the $\mathrm{T}$ - test and assuming unequal variance. A significant positive difference between the estimated alphas would imply that one managers' group on average has better stock selection capabilities than its counterpart. Similarly a positive beta difference would imply that this managers' group is more market sensitive than its counterpart too (Dawood, 2013). Finally,to test the research hypotheses, the empirical results obtained from applyingboth of Jensen (1968) and Treynor\&Mazuy (1966) models during-and-post-period of the FC, in addition to Hayat and Kraeussl approach will be presented in the next section to show the significance of these regressionmodels coefficients.

\section{Empirical Results}

\subsection{Performance based on Jensen's alpha regression model}

By applying the single index model of the first equation; the mutual funds sample is regressioned against the two benchmarks; the results are displayed in the two sub-sections of Table 2. Panel A of Section 1 of this table shows that when compared to the EGX30 index over the entire period, all of the seven funds groups show overall negative selectivity skills; where alpha is negative and statistically significant, but because 
of the insignificant under-performance of the Fixed Income funds group, the whole under-performance of the overall funds on average found to be statistically insignificant indicating that if all funds groups were unable to overcome their relative index and have no any selectivity skills, the market cannot significantly beat the whole funds on average. On the other hand, when compared to the EGX30 index too, both of $\mathrm{CMF}_{\mathrm{S}}$ and $\mathrm{IMF}_{\mathrm{S}}$ show statistically significant negative performance despite the existence of the fixed income funds between the components of the conventional category. This result differs from the findings of Beehary et al., (2009) in Mauritian, who refer that fund managers are significantly able to beat the market through their stock picking skills, and Evangelos (2009) in Turkey, who find persistence in the ability of stock selection among the very best and worst performers, but on other hand it consistent with other research studies in other Islamic emerging economics such this of Shazia et al., (2010) in Pakistan; Samira and Slaheddine (2011) in Tunis; and Reza et, al., (2011) in Iran, and Fikriyah, et al., (2007) in Malaysia, who conclude that the majority of fund managers on average are not engaged in stock selectivity.

\subsection{Performance based on Treynor\&Mazuy' regression models}

By examining funds' gamma and average gamma for different funds groups usingTreynor\&Mazuy (1966) model of the second equation. Estimated alpha andgamma are presented in Table 3. The first regression measures the total period; as reported in Panel A of table 3, portfolios'gamma for the overall funds and for funds in different groups including both of Islamic and conventional categories is insignificantfor the whole period of 2007-2012 suggesting that managers on average do not have any superior market timing skills. This result is also agreed with those of Islamic emerging economics that was mentioned previously except of Mauritian, and differs from these of Amporn \& Yosawee (2011); Sit \& Manuel (2011); and Craig and Micael (1997) in other Non-Islamic premature economic, who report that fund managers can timing their markets. Once again, to verify the impact of the (FC) on funds gamma, Panel B of table 3 displays the funds gamma results with the dummy variable for the period 2007-2008. Similar to the results reported in Panels A, the average gamma for the overall funds and both of conventional and Islamic is insignificantfor the 2007-2008 periods, while the estimated coefficient of the dummy variable for the overall funds is negative across the same two years period, but insignificant as well. It finally seems that on average too fund managers cannot anticipate their market movements during and after the (FC) referring that (FC) has no impact on the managers' performance. These results are exactly the same for the two investigated indexes. This result also consistent with the findings of Fung et al., (2002); French \& Ko (2007) and Park (2010) who show that there is no statistically significant evidence of market timing for fund managers across the (FC).To show the results of measuring both managers' skills across the whole period, taking the market collapse into consideration, Table 4 Sections 1 and 2 summarize the funds' performance results. It explains the difference in funds' numbers that report significantly positive and negative performance during the down-market period. For Jensen regression model, the number of positive funds dropped from 19 to zero funds; the alpha coefficient for one of these funds was insignificant, leaving18 funds that negatively and significantly impacted by the dropped market. Similarly, for Treynor and Mazuy' model, the number of negative funds increased from 26 to 29 funds, but the 
gammacoefficient for 5 funds only were significant referring that the fallen market has worsen the performance of 5 funds.

\subsection{The regression line stability}

In order to investigate the validityof the claim that the $\mathrm{FC}$ has also taken place in Egypt during 2007-2008 periods, we run Chow-Test after dividing the entire period into two sub-periods as an initial procedure for testing the null hypothesis of the regression coefficients and line stability. Table 5 presents the results of the estimated F-Ratio after utilizing EGX30 returns as independent variable. As shown in this table the value of FRatio (1.34) is lower than both (3.01) and (4.61) that match the significance levels of 5\% and $1 \%$ respectively. It implies accepting the null hypothesis referring that there are no structural changes either for the regression line or for the regression coefficients across the two sub-periods. This result clearly explains the reasons of fund managers' performance similarity across the two sub-periods as it was mentioned previously. This in turn either means that the Egyptian stock market has not been affected by the FC or means that it has been affected by it, but at a different time, which needs to be discussed in subsequent studies.

\subsection{Significance of differences between CMFS and IMFS performances}

To test the significance of differences between $\mathrm{CMF}_{\mathrm{S}}$ and $\mathrm{IMF}_{\mathrm{S}}$ performances; $\mathrm{T}$ - test is conducted for alpha and beta estimations of both fund groups. Table 6 displays the results of this test. As shown in Panel A, the alpha coefficients for both $\mathrm{CMF}_{\mathrm{S}}$ and $\mathrm{IMF}_{\mathrm{S}}$ are not statistically different implying that no one of them performed better than its counterpart over the period 2007-2012, which supports the result revealed by verifying the first hypothesis. When measuring the market risk, it is found that the beta coefficients for both types are not statistically different, suggesting that these funds, on average, have a similar systematic risk as adopted by their respective benchmark. As also shown in Table 8; Panels B reports the T-test statistics on the equality of standard deviations of alpha and beta coefficients as suggested by Levene (1960). The similarity between the standard deviations of estimated alphas for the two groups implies that the stock selection ability of $\mathrm{CMF}_{\mathrm{S}}$ and IMFs fluctuates in parallel and, therefore, no group too is riskier than the other. As expected, the standard deviation of the estimated alpha coefficient of $\mathrm{CMF}_{\mathrm{S}}$ is not significantly different from that of the IMFs. If read together, the similarity of mean and standard deviations between $\mathrm{CMF}_{S}$ and IMFs implies that $\mathrm{CMF}_{\mathrm{S}}$ have no better selectivity ability than IMFs. However, these proxies of comparable returns are attributed to the similar level of market risk they both expose across the total period. This result differs from that of Luis et al., (2012) who add that religious mutual fund managers underperform their conventional counterparts.

\section{Conclusion}

The recent study displays a comprehensive analysis of the Egyptian mutual funds' performance for the period 2007-2012. Literature review of funds' performance find mixed results on the evidence of over-or-under-performance across mature, premature, and emerging economics (Islamic/Non-Islamic). Using a sample of 35 out of 87 mutual funds, this paper examined the two manager skills of market timing and stock picking. It added to the recent literature by exploring the impact of the down-market of 
2007-2008 on funds' performance from one side; in addition to investigating the differences in performance between $\mathrm{CMF}_{S}$ and $\mathrm{IMF}_{\mathrm{S}}$ from the other side. The performance results for the two regression models of Jensen (1966), and Treynor\&Mazuy, (1966) are the same. Funds' performance is negative, but insignificant over the entire period; the result remains the same when accounting for the downmarket of 2007-2008 period, where there are no structural changes for the regression line across the two investigated sub-periods; meanwhile, the estimated coefficients for the downturn dummy variable is negative and insignificant too. The Egyptian $\mathrm{CMF}_{\mathrm{S}}$ and $\mathrm{IMF}_{\mathrm{S}}$ showed no statistically differences in performance along the overall period, where, the $\mathrm{p}$-value of the T-test for both of the mean and standard deviation for the estimated alpha and beta coefficients is insignificant. It appears that the whole fund managers are not able to out-perform the market even for the total period or for the fallen-market period due to their poor skills of stock picking and stock allocation. To this extent, this article result on the Egyptian fund managers performance consistent nearly with the prior studies that conducted in most emerging economicsexcept for Turkey, and Mauritian, where, Evangelos, (2009); and Beehary et al., (2009) for example and respectively, reported that fund managers have significant positive stock selectivity and market timing skills.

\section{References}

Abul Hassan, A. and Krishna, P. (2005), "Impact of Ethical Screening on Investement Performance: The case of the Dow Jones Islamic Index". Islamic Economic Studies. Vol. 12, No. 2 \& Vol. 13, No. 1, February \& August 2005.

Amporn Soongswang; and Yosawee Sanohdontree. (2011), "Open-Ended Equity Mutual Funds", International Journal of Business and Social Science 2. 17 (Sep 2011): $\mathrm{n} / \mathrm{a}$.

Bakri, A., Wong, S., Zulkefly, A. and Mohamad, J. (2012), "The Impact of Subprime Mortgage Crisis on Islamic Banking and Islamic Stock Market", International Congress on Interdisciplinary Business and Social Science (ICIBSoS). Procedia - Social and Behavioral Sciences 65 ( 2012 ) 668 - 673.

Beehary Nitish, Rojid Sawkut, Seetanah Boopen, Sannassee Vinesh and Fowdur Suraj. (2009), "Analyzing Mutual Funds Performance: The Case of Emerging Mauritian Economy", The IUP Journal of Financial 48 Economics, Vol. VII, No. 2.

Cave. A, Hubner. G, and Sougne. D. (2012). "The market timing skills of hedge funds during the financial crisis". Managerial Finance. Vol. 38 No. 1, 2012. pp. 4-26.

Chen, Y. (2007), "Timing ability in the focus market of hedge funds", Journal of Investment Management, Vol. 5 No. 1, pp. 66-98.

Chen, Y. and Liang, B. (2007), "Do market timing hedge funds time the market?", Journal of Financial and Quantitative Analysis, Vol. 42 No. 4, pp. 827-56.

Chow G. (1960), "Tests of equality between sets of coefficients in two linear regressions". Econometria, 28 (3), 591-605.

Christian, W. and Sebastian, L. (2012), "Islamic investing", Review of Financial Economics 21 (2012) 53-62.

Craig, E., Oldfield, and Michael J. P. (1997), "Assessing portfolio performance: The case of South African Unit trusts”, Investment Analysis Journal - No. 44 summer 1997.

David H., Mingyi, and Pedro. (2012), "Corporate governance in the 2007-2008 financial crisis: Evidence from financial institutions worldwide", Journal of Corporate Finance 18. Pg. 292.

Dawood, A. (2013), "Performance evaluation of Islamic mutual funds relative to conventional funds: Empirical evidence from Saudi Arabia", SSRN Working Paper Series, Jan 2013.

Egypt for Information Dissemination (EGID). Block 72 off 90 Axis - El Tagmoaa El Khames, New Cairo ,Helwan. www.egyptse.com

Elton, E. J., Gruber, M. J., \& Green, C. T. (2007), "The impact of mutual fund family membership on investor risk", Journal of Financial and Quantitative Analysis. 42, 257-278. 
Evangelos, B. (2009), Essays in mutual fund performance, the home equity bias and the effects of financial frictions on output and occupational choice. ProQuest dissertations and theses; ABI/INFORM Global. Pg. n/a.

Fikriyah, A., Taufiq, H., and Shamsher, M. (2007), "nvestigation of performance of Malaysian Islamic unit trust funds: Comparison with conventional unit trust funds", Managerial Finance Vol. 33 No. 2, 2007 pp. 142-153.

French, C. and Ko, D. (2007), "How hedge funds beat the market?", Journal of Investment

Fung, H.G., Xu, X.E. and Yau, J. (2002), “Global hedge funds: risk, return, and market timing”, Financial Analysts Journal, Vol. 58 No. 6, pp. 19-30.

George, A., Peter, C. and Marie, R. (1998), "How effective is aggressive portfolio management?: mutual fund performance in Canada", 1985 - 1996. Available at: http://www.investmentreview.com/files/2009/12/management1.pdf

Hassan K. and Kayed R. ( 2010), "The Global Financial Crisis and Islamic Finance". Available at: www.sesric.org/imgs/news/image/585-paper-1.

Hayat, R. and Kraeussl,R. (2011), "Risk and return characteristics of Islamic equity funds", Emerging Markets Review 12 (2011) 189-203.

Heaney, R.; Hallahan, T.; Josef, T.; and Mitchell, H. (2007), "Time-Changing Alpha? The Case of Australian International Mutual Funds", Australian Journal of Management; Jun 2007; 32, 1; ABI/INFORM Global. pg. 95.

Hubner, G., Cave, and Arnaud. (2012), "The market timing skills of hedge funds during the financial crisis". Managerial Finance 38. 1 : 4-26.

Kaushik, A. And Pennathur A. K. (2012), "An empirical examination of the performance of real estate mutual funds 1990-2008". Financial Services Review 21. PP. 343-358.

Keith, C., Dirk, N., and Niall, O. (2008), "UK mutual fund performance: Skill or luck?", Journal of Empirical Finance 15 - 613-634.

Luis, F., Fernando, M., and Ruth, V. (2011), "Effect of Positive Screens on Financial Performance: Evidence from Ethical Mutual Fund Industry". Available at: http://www.efmaefm.org/0EFMAMEETINGS/EFMA\%20ANNUAL\%20MEETINGS/2012Barcelona/papers/EFMA2012_0183_fullpaper.pdf.

Luis Ferruz, Fernando Munoz and Marı Vargas. (2012), "Managerial Abilities: Evidence from Religious Mutual Fund Managers", J Bus Ethics 105:503-517.

Marketing Week (Dec 6, 2012): Available at: http://search.proquest.com/docview/1223834623? accountid=40625.

Miranti, K.D., and Ilham, R.F. (2012), "Evaluating Performance of Islamic Mutual Funds in Indonesia and Malaysia". Journal of Applied Economics and Business Research. JAEBR, 2(1): 11-33 (2012).

Monarcha, G. (2011), "A dynamic style analysis model for hedge funds”, Quantitative Research No. 1, Orion Financial Partners, Paris.

Murhadi, W.R. (2010), "Performance Evaluation of Mutual Funds in Indonesia". SSRN Working Paper Series, Sep 2010.

Nafis Alam. (2010) "Resilience of Islamic Finance During Credit Crunch - Empirical Evidence from European Market". $8^{\text {th }}$ International Conference on Islamic Economics and Finance. Available at: http://conference.qfis.edu.qa/app/media/218

Nafis, Alam (2013), "A comparative performance analysis of conventional and Islamic exchange-traded funds", Journal of Asset Management 14.1 (Feb 2013): 27-36.

Naughton, S. \& Naughton, T. (2000), "Religion, ethics and stock trading: The case of an Islamic equities market". Journal of Business Ethics, 23, 145-159.

Phaniswara B. Raju and Mallikarjuna K. Rao. (2009), "Market Timing Ability of Selected Mutual Funds in India", A Comparative Study. IUP Journal of Applied Finance15. 3 (Mar 2009): 34-48.

Park, H. (2010), "Can factor timing explain hedge fund alpha?", working paper, Minnesota State University, Mankato, December 23.

Reza, D., Sara, F. and Hamed, M., (2011), "Market timing in investment companies and mutual funds. Evidence from Iran". World Applied Science Journal 13 (8): 1793-1799, ISSN 1818-4952.

Roberto, C., Loriana, P. and Andrea, P. "Italian Equity Funds: EfficiencyAnd performance Persistence", Available http://www.researchgate.net/publication/23698408_Italian_Equity_Funds_Efficiency and Perf ormance Persistence/file/d912f50e507c439f52.pdf. 
Samira, B.B. and Slaheddine, H. (2011), "Predicting Tunisian mutual fund performance using dynamic panel data model", The Journal of Risk Finance. Vol. 12 No. 3, 2011. pp. 208-225

Shazia, I., Zaheer, A., and Amir, S. (2010), "Performance Evaluation of Close-ended Mutual Funds by Investment Objectives in Pakistan's Economy". INTERDISCIPLINARY JOURNAL OF CONTEMPORARY RESEARCH IN BUSINESS. AUGUST 2010, VOL 2, NO 4.

Sit, C. and Manuel, O. (2011), "ARE PHILIPPINE FIXED INCOME FUND MANAGERS GENERATING ALPHA FOR THEIR CLIENTS?”, Journal of International Business Research, suppl. Special Issue10. 3 (2011): 129-152.

Stefano, C., Stefano, G. (2009), "Islamic Equity Funds: an Italian perspective". Available at: http://uaelaws.files.wordpress.com/2012/02/islamic-equity-funds-italian-perspective.pdf

Treynor and Mazuy. (1966), "Can Mutual Funds Outguess The Markets” Harvard Business Review, Vol. 44, pp.131-136.

Yang-pin, S., Chiuling, L. and Zong-Han, L. (2012), "International Real Estate Mutual Fund Performance: Diversification or Costly Information?”, J Real Estate Finan Econ 44:394-413.

Yue-Cheong, C., Louis, T., and W. Cheng. (2003), "Asset Allocation and Selectivity of Asian Mutual Funds During Financial Crisis", Review of Quantitative Finance and Accounting; Nov 2003; 21, 3; ABI/INFORM Global. pg. 233.

Table 2 The results of the CAPM regression model;this table reports the results of the estimation of Eq. (1) for the 31/12/2006:30/06/ 2012 period. Reported estimates are OLS estimates for both of overall and conventional funds groups in addition to the other seven investment categories (Equity, Fixed Income, Balanced, Islamic, Asset Allocator, Income Mixed, and other) across the sub-periods of the FC.

\begin{tabular}{|c|c|c|c|c|c|c|c|c|}
\hline & & & & $\begin{array}{l}\text { Panel A } \\
\text { Overall } \\
\text { Period }\end{array}$ & & & $\begin{array}{l}\text { Panel B } \\
\text { Crisis } \\
\text { Period }\end{array}$ & \\
\hline Sample & $\begin{array}{l}\text { No of } \\
\text { Funds }\end{array}$ & Obs. & Variable & $\begin{array}{l}\text { Estimated } \\
\text { Value }\end{array}$ & p-value & Variable & $\begin{array}{l}\text { Estimated } \\
\text { Value }\end{array}$ & p-value \\
\hline Overall & 35 & 275 & $\begin{array}{l}\text { Alpha } \\
\text { Beta }\end{array}$ & $\begin{array}{l}-0.007 \\
0.311\end{array}$ & $\begin{array}{l}0.274 \\
0.000\end{array}$ & $\begin{array}{l}\text { Alpha } \\
\text { Beta } \\
\text { Dummy }\end{array}$ & $\begin{array}{l}-0.003 \\
0.313 \\
-0.007\end{array}$ & $\begin{array}{l}.726 \\
0.000 \\
0.561 \\
\end{array}$ \\
\hline Conventional & 31 & 015 & $\begin{array}{l}\text { Alpha } \\
\text { Beta }\end{array}$ & $\begin{array}{l}-0.010 \\
0.203\end{array}$ & $\begin{array}{l}0.003^{(* *)} \\
0.000\end{array}$ & $\begin{array}{l}\text { Alpha } \\
\text { Beta } \\
\text { Dummy }\end{array}$ & $\begin{array}{l}-0.014 \\
0.201 \\
0.006 \\
\end{array}$ & $\begin{array}{l}0.460 \\
0.000 \\
0.443\end{array}$ \\
\hline Islamic & 4 & 60 & $\begin{array}{l}\text { Alpha } \\
\text { Beta }\end{array}$ & $\begin{array}{l}-0.009 \\
0.246\end{array}$ & $\begin{array}{l}0.050^{(* *)} \\
0.000\end{array}$ & $\begin{array}{l}\text { Alpha } \\
\text { Beta } \\
\text { Dummy }\end{array}$ & $\begin{array}{l}-0.014 \\
0.243 \\
0.010 \\
\end{array}$ & $\begin{array}{l}0.034^{(* *)} \\
0.000 \\
0.285\end{array}$ \\
\hline Equity & 14 & 10 & $\begin{array}{l}\text { Alpha } \\
\text { Beta }\end{array}$ & $\begin{array}{l}-0.018 \\
0.412\end{array}$ & $\begin{array}{l}0.000^{(* *)} \\
0.048\end{array}$ & $\begin{array}{l}\text { Alpha } \\
\text { Beta } \\
\text { Dummy }\end{array}$ & $\begin{array}{l}-0.021 \\
0.410 \\
0.007 \\
\end{array}$ & $\begin{array}{l}0.032^{(* *)} \\
0.000 \\
0.608\end{array}$ \\
\hline $\begin{array}{l}\text { Fixed } \\
\text { Income }\end{array}$ & 6 & 90 & $\begin{array}{l}\text { Alpha } \\
\text { Beta }\end{array}$ & $\begin{array}{l}-0.003 \\
0.013\end{array}$ & $\begin{array}{l}0.244 \\
0.673\end{array}$ & $\begin{array}{l}\text { Alpha } \\
\text { Beta } \\
\text { Dummy }\end{array}$ & $\begin{array}{l}-0.004 \\
0.013 \\
0.002 \\
\end{array}$ & $\begin{array}{l}0.000^{(* * *)} \\
0.057 \\
0.247\end{array}$ \\
\hline Balanced & 5 & 25 & $\begin{array}{l}\text { Alpha } \\
\text { Beta }\end{array}$ & $\begin{array}{l}-0.013 \\
0.203\end{array}$ & $\begin{array}{l}0.012^{(* *)} \\
0.000\end{array}$ & $\begin{array}{l}\text { Alpha } \\
\text { Beta } \\
\text { Dummy }\end{array}$ & $\begin{array}{l}-0.017 \\
0.201 \\
0.007 \\
\end{array}$ & $\begin{array}{l}0.024^{(* *)} \\
0.000 \\
0.483 \\
\end{array}$ \\
\hline $\begin{array}{l}\text { Closed } \\
\text { End }\end{array}$ & 3 & 195 & $\begin{array}{l}\text { Alpha } \\
\text { Beta }\end{array}$ & $\begin{array}{l}-0.016 \\
0.051\end{array}$ & $\begin{array}{l}0.002^{(* * *)} \\
0.284\end{array}$ & $\begin{array}{l}\text { Alpha } \\
\text { Beta } \\
\text { Dummy }\end{array}$ & $\begin{array}{l}-0.024 \\
0.046 \\
0.015 \\
\end{array}$ & $\begin{array}{l}0.001^{(\text {(**) }} \\
0.329 \\
0.123\end{array}$ \\
\hline $\begin{array}{l}\text { Asset } \\
\text { Allocator }\end{array}$ & 2 & 130 & $\begin{array}{l}\text { Alpha } \\
\text { Beta }\end{array}$ & $\begin{array}{l}-0.017 \\
0.337\end{array}$ & $\begin{array}{l}0.048^{(* *)} \\
0.000 \\
\end{array}$ & $\begin{array}{l}\text { Alpha } \\
\text { Beta } \\
\text { Dummy }\end{array}$ & $\begin{array}{l}-0.018 \\
0.336 \\
0.002 \\
\end{array}$ & $\begin{array}{l}0.137 \\
0.000 \\
0.885 \\
\end{array}$ \\
\hline $\begin{array}{l}\text { Income } \\
\text { Mixed }\end{array}$ & 1 & 65 & $\begin{array}{l}\text { Alpha } \\
\text { Beta }\end{array}$ & $\begin{array}{l}-0.009 \\
0.015 \\
\end{array}$ & $\begin{array}{l}0.504 \\
0.900\end{array}$ & $\begin{array}{l}\text { Alpha } \\
\text { Beta } \\
\text { Dummy }\end{array}$ & $\begin{array}{l}-0.036 \\
-0.027 \\
0.029 \\
\end{array}$ & $\begin{array}{l}\left.0.077^{*}\right) \\
0.845 \\
0.303 \\
\end{array}$ \\
\hline
\end{tabular}

* Egyptian revolution led to the closure of the Egyptian Stock Exchange since the end of January to the end of March 2011 , so the number of observations is 65 instead of 66 ones. 
Table 3 The market timing ability of the fund managers; this table displays the regression results of estimating the market timing ability of Eq. (2) for the seven investment categories (Islamic, Equity, Fixed Income, Balanced, closed end, Asset Allocator, and Income Mixed) in addition to the overall funds in average over the period from 31/12/2006 to 30/06/ 2012 during-and-post the financial crisis. It illustrates the results of the Treynor and Mazuy (1966) model, where alpha, beta, and gamma are indicating outperformance, systematic risk, and market timing ability, respectively.

\begin{tabular}{|c|c|c|c|c|c|c|c|c|}
\hline & & & & $\begin{array}{l}\text { Panel A } \\
\text { Overall } \\
\text { Period }\end{array}$ & & & $\begin{array}{l}\text { Panel B } \\
\text { Crisis Perio }\end{array}$ & \\
\hline Sample & $\begin{array}{l}\text { No of } \\
\text { Funds }\end{array}$ & Obs & Variable & $\begin{array}{l}\text { Estimated } \\
\text { Value }\end{array}$ & -value & Variable & $\begin{array}{l}\text { Estimated } \\
\text { Value }\end{array}$ & $\begin{array}{l}\mathrm{p}- \\
\text { value }\end{array}$ \\
\hline Overall & 5 & 275 & $\begin{array}{l}\text { Alpha } \\
\text { Beta } \\
\text { Gamma }\end{array}$ & $\begin{array}{l}-0.003 \\
0.298 \\
-0.365\end{array}$ & $\begin{array}{l}0.664 \\
0.000 \\
0.294\end{array}$ & $\begin{array}{l}\text { Alpha } \\
\text { Beta } \\
\text { Gamma } \\
\text { Dummy }\end{array}$ & $\begin{array}{l}-0.000 \\
0.301 \\
-0.350 \\
-0.006\end{array}$ & $\begin{array}{l}0.992 \\
0.000 \\
0.318 \\
0.621\end{array}$ \\
\hline Conventional & 1 & 015 & $\begin{array}{l}\text { Alpha } \\
\text { Beta } \\
\text { Gamma }\end{array}$ & $\begin{array}{l}-0.012 \\
0.207 \\
0.118\end{array}$ & $\begin{array}{l}0.004 \\
0.000 \\
0.518\end{array}$ & $\begin{array}{l}\text { Alpha } \\
\text { Beta } \\
\text { Gamma } \\
\text { Dummy }\end{array}$ & $\begin{array}{l}-0.015 \\
0.204 \\
0.105 \\
0.006\end{array}$ & $\begin{array}{l}0.006 \\
0.000 \\
0.569 \\
0.385\end{array}$ \\
\hline Islamic & & 60 & $\begin{array}{l}\text { Alpha } \\
\text { Beta } \\
\text { Gamma }\end{array}$ & $\begin{array}{l}-0.011 \\
0.254 \\
-0.229\end{array}$ & $\begin{array}{l}0.031 \\
0.000 \\
0.344\end{array}$ & $\begin{array}{l}\text { Alpha } \\
\text { Beta } \\
\text { Gamma } \\
\text { Dummy }\end{array}$ & $\begin{array}{l}-0.016 \\
0.251 \\
0.209 \\
0.009 \\
\end{array}$ & $\begin{array}{l}0.023 \\
0.000 \\
0.391 \\
0.322 \\
\end{array}$ \\
\hline Equity & 4 & 10 & $\begin{array}{l}\text { Alpha } \\
\text { Beta } \\
\text { Gamma }\end{array}$ & $\begin{array}{l}-0.012 \\
0.392 \\
-0.568\end{array}$ & $\begin{array}{l}0.131 \\
0.000 \\
0.119\end{array}$ & $\begin{array}{l}\text { Alpha } \\
\text { Beta } \\
\text { Gamma } \\
\text { Dummy }\end{array}$ & $\begin{array}{l}-0.016 \\
0.394 \\
-0.587 \\
0.009\end{array}$ & $\begin{array}{l}0.088 \\
0.000 \\
0.093 \\
0.415\end{array}$ \\
\hline $\begin{array}{l}\text { Fixed } \\
\text { Income }\end{array}$ & & 90 & $\begin{array}{l}\text { Alpha } \\
\text { Beta } \\
\text { Gamma }\end{array}$ & $\begin{array}{l}-0.003 \\
0.013 \\
-0.008\end{array}$ & $\begin{array}{l}0.000 \\
0.059 \\
0.827\end{array}$ & $\begin{array}{l}\text { Alpha } \\
\text { Beta } \\
\text { Gamma } \\
\text { Dummy }\end{array}$ & $\begin{array}{l}-0.004 \\
0.012 \\
-0.012 \\
0.002\end{array}$ & $\begin{array}{l}0.001 \\
0.073 \\
0.751 \\
0.242\end{array}$ \\
\hline Balanced & & 25 & $\begin{array}{l}\text { Alpha } \\
\text { Beta } \\
\text { Gamma }\end{array}$ & $\begin{array}{l}-0.012 \\
0.200 \\
0.081\end{array}$ & $\begin{array}{l}0.040 \\
0.000 \\
0.770\end{array}$ & $\begin{array}{l}\text { Alpha } \\
\text { Beta } \\
\text { Gamma } \\
\text { Dummy }\end{array}$ & $\begin{array}{l}-0.016 \\
0.197 \\
-0.098 \\
0.007\end{array}$ & $\begin{array}{l}0.043 \\
0.000 \\
0.725 \\
0.470\end{array}$ \\
\hline $\begin{array}{l}\text { Closed } \\
\text { End }\end{array}$ & & 95 & $\begin{array}{l}\text { Alpha } \\
\text { Beta } \\
\text { Gamma }\end{array}$ & $\begin{array}{l}-0.018 \\
0.057 \\
0.162\end{array}$ & $\begin{array}{l}0.002 \\
0.245 \\
0.546\end{array}$ & $\begin{array}{l}\text { Alpha } \\
\text { Beta } \\
\text { Gamma } \\
\text { Dummy }\end{array}$ & $\begin{array}{l}-0.025 \\
0.051 \\
0.128 \\
0.015 \\
\end{array}$ & $\begin{array}{l}0.001 \\
0.295 \\
0.631 \\
0.137\end{array}$ \\
\hline $\begin{array}{l}\text { Asset } \\
\text { Allocator }\end{array}$ & & 30 & $\begin{array}{l}\text { Alpha } \\
\text { Beta } \\
\text { Gamma }\end{array}$ & $\begin{array}{l}-0.014 \\
0.325 \\
0.347\end{array}$ & $\begin{array}{l}0.172 \\
0.000 \\
0.459\end{array}$ & $\begin{array}{l}\text { Alpha } \\
\text { Beta } \\
\text { Gamma } \\
\text { Dummy }\end{array}$ & $\begin{array}{l}-0.015 \\
0.323 \\
-0.355 \\
0.004\end{array}$ & $\begin{array}{l}0.243 \\
0.000 \\
0.453 \\
0.835\end{array}$ \\
\hline $\begin{array}{l}\text { Income } \\
\text { Mixed }\end{array}$ & & 5 & $\begin{array}{l}\text { Alpha } \\
\text { Beta } \\
\text { Gamma }\end{array}$ & $\begin{array}{l}-0.025 \\
-0.006 \\
0.311\end{array}$ & $\begin{array}{l}0.138 \\
0.965 \\
0.688\end{array}$ & $\begin{array}{l}\text { Alpha } \\
\text { Beta } \\
\text { Gamma } \\
\text { Dummy }\end{array}$ & $\begin{array}{l}-0.038 \\
-0.018 \\
0.264 \\
0.028\end{array}$ & $\begin{array}{l}0.078 \\
0.900 \\
0.752 \\
0.321\end{array}$ \\
\hline
\end{tabular}


Table 4 The comparative performanceof the funds across the two models during and after the financial crisis.

\begin{tabular}{|c|c|c|c|c|c|c|c|}
\hline Model & $\begin{array}{l}\text { No. of } \\
\text { Funds }\end{array}$ & Positive & Negative & Sig & Insig & $\begin{array}{l}\text { Positive } \\
\text { andSig }\end{array}$ & $\begin{array}{l}\text { Negativeand } \\
\text { Sig }\end{array}$ \\
\hline Jensen' alpha & 35 & 19 & 16 & 0 & 35 & 0 & 0 \\
\hline $\begin{array}{l}\text { Jensen' alpha with } \\
\text { dummy }\end{array}$ & 35 & 0 & 35 & 18 & 17 & 0 & 18 \\
\hline $\begin{array}{l}\text { Treynor and } \\
\text { Mazuy' gamma }\end{array}$ & 35 & 9 & 26 & 3 & 32 & 0 & 3 \\
\hline $\begin{array}{l}\text { Treynor and } \\
\text { Mazuy' gamma } \\
\text { with dummy }\end{array}$ & 35 & 6 & 29 & 5 & 30 & 0 & 5 \\
\hline
\end{tabular}

Table 5 Regression line stability. This table reports the results of investigating the null hypothesis of the regression line breaks lack across the two sub-periods of 2007-2008 and 2009-2012 depending on EGX30 index.

\begin{tabular}{lcccccccc}
\hline Period & $\begin{array}{l}\text { Sum of } \\
\text { Squares }\end{array}$ & Df & $\begin{array}{l}\text { No of } \\
\text { bs }\end{array}$ & $\begin{array}{l}\text { No of } \\
\text { Parameters }\end{array}$ & $\begin{array}{l}\text { F } \\
\text { Value }\end{array}$ & $\begin{array}{l}\text { F } \\
\text { Table }\end{array}$ & $\begin{array}{l}\text { S - } \\
\text { Level }\end{array}$ \\
\hline Total Period & 5 & 0.166 & & & & & 3.01 & $\%$ \\
FC - Period & 4 & 0.009 & 4 & & 2 & 1.34 & & \\
$\begin{array}{l}\text { Post-Crisis } \\
\text { Period }\end{array}$ & 1 & 0.150 & 3 & 5 & & & .64 & $\%$ \\
\hline
\end{tabular}

Table 6 Difference in means and standard deviation analysis depending on EGX30 index; this table reports the results of differences in means and standard deviation analysis resulted from a cross section analysis for the CAPM regression coefficients for 18 Egyptian mutual funds between December 2006 and June 2012. Panel A reports the difference in means of equity CMFs and IMFs based on unequal variance. Panel B reports the difference in standard deviation based on Levene's robust test statistic for the equality of variances between equity CMFs and IMFs.

\begin{tabular}{|c|c|c|c|c|c|c|c|}
\hline & Variable & Sample & Mean & Std. dev & Std. error & t-stat & Sig \\
\hline Panel & Alpha & Conventional & 0.0089 & 0.01095 & 0.0293 & -0.289 & 0.777 \\
\hline $\mathbf{A}$ & & Islamic & 0.0105 & 0.0420 & 0.0210 & -0.456 & 0.656 \\
\hline Differences & Beta & Conventional & 0.7460 & 0.34144 & 0.09125 & -1.221 & .240 \\
\hline In Mean & & Islamic & 0.9680 & 0.20886 & 0.10443 & -1.601 & 0.147 \\
\hline Panel & Alpha & Conventional & 0.0112 & 0.00112 & 0.00030 & -0.061 & 0.952 \\
\hline B & & Islamic & 0.0113 & 0.00050 & 0.00025 & -0.091 & 0.929 \\
\hline Differences & Beta & Conventional & 0.1336 & 002978 & 0.00796 & -1.547 & 0.141 \\
\hline In S.Dev & & Islamic & 0.1593 & 0.02695 & 0.01347 & -1.641 & 0.158 \\
\hline
\end{tabular}

